\title{
Clinical Anatomy of the Head Region of the Black Bengal Goat in Bangladesh
}

\author{
Anatomía Clínica de la Región de la Cabeza de la Cabra Negra Bengal en Bangladesh
}

\author{
"Mohammad Mejbah Uddin; ${ }^{* *}$ Syed Sayeem Uddin Ahmed; ${ }^{* * *}$ Kh. Nurul Islam \& ${ }^{* * * *}$ Md. Mominul Islam
}

UDDIN, M. M.; AHMED, S. S. U.; ISLAM, K. N. \& ISLAM, M. M. Clinical anatomy of the head region of the Black Bengal goat in Bangladesh. Int. J. Morphol., 27(4):1269-1273, 2009.

SUMMARY: The study involved the measurements of some clinically important landmarks for regional anesthesia in the maxillary and mandibular regions of head of fifty Black Bengal (BB) goats. The distance from facial tuberosity to the infra-orbital canal and from the latter to the root of the alveolar tooth directly ventral to it were $1.85 \mathrm{~cm}$ and $1.75 \mathrm{~cm}$ respectively. Both the distances from facial tuberosity to infra-orbital canal and from infra-orbital canal to the root of the alveolar tooth are of clinical important even in live animal as a guide for tracking infra-orbital nerve because of facial tuberosity. The distance between the lateral end of the alveolus of the incisor tooth to the mental foramen was $2.11 \mathrm{~cm}$ and are from the mental foramen to the caudal mandibular border was $11.69 \mathrm{~cm}$ and important for the regional anesthesia of mental nerve. The length and maximum height of the mandibles were $14.21 \mathrm{~cm}$ and $8.83 \mathrm{~cm}$ respectively. The distance from Caudal border of mandible to below mandibular foramen was $1.47 \mathrm{~cm}$, while the distance from the mandibular foramen to the base of the mandible, Caudal border of mandibular to the level of mandibular foramen and mandibular foramen to border of mandibular angle were $3.64 \mathrm{~cm}, 0.90 \mathrm{~cm}$ and $2.65 \mathrm{~cm}$ respectively. Parameters regarding mandible are of c linical important landmarks and will be guide for the regional anesthesia of mandibular nerve block. However, these data was discussed with regard to their application in proper tracking of infra-orbital, mental and mandibular nerves in aid of regional anesthetic procedures for the clinical affection around the head of the Black Bengal goat.

KEY WORDS: Mandible; Maxilla; Regional Anesthesia; Goat.

\section{INTRODUCTION}

Black Bengal goat is the only recognized breed among the domestic species in Bangladesh. The goats are known to be famous for their adaptability, prolificacy, delicacy of meat and superior skin quality. They have tremendous demand all over the world due to production of extra ordinary quality meat and skin (Islam et al., 1991; Singh et al., 1990, 1991).

The form and relationships of all organs located in a particular area are directly concerned with regional anatomy which helps the clinician as well as surgeon to visualize details of structures relevant to the case at hand and form one of the important foundations for clinical and surgical practice (Dyce et al., 1996).

Vital organs and structures such as the brain, tongue, eyes, ears, teeth, nose, lips, horn and skull are situated in head region. The regional anatomy of head region is needed for coordination of the body as well as for deglutition, olfaction and defiance (Dyce et al.; Olopade, 2003) especially the foramina in the skull are very important for clinical, surgical aspect and regional anesthesia around the

\footnotetext{
Assistant Professor, Department of Anatomy and Histology, Faculty of Veterinary Medicine, Chittagong Veterinary and Animal Sciences University, Khulshi, Chittagong-4202. Bangladesh. E-mail: mmu_cvasu@yahoo.com

** Assistant Professor, Department of Medicine and Surgery, Faculty of Veterinary Medicine, Chittagong Veterinary and Animal Sciences University, Khulshi, Chittagong-4202, Bangladesh. E-mail: sayeem_2000@yahoo.com

*** Professor and Head, Department of Anatomy and Histology, Faculty of Veterinary Medicine, Chittagong Veterinary and Animal Sciences University, Khulshi, Chittagong-4202, Bangladesh. E-mail: knislam@yahoo.com

${ }^{* * * *}$ Research Student, Department of Anatomy and Histology, Faculty of Veterinary Medicine Chittagong Veterinary and Animal Sciences University, Khulshi, Chittagong-4202. Bangladesh. E-mail: momindvm@yahoo.com
} 
head (Hall et al., 2000). Some previous work had been done on the heads of domestic animals including the horse, ox, dog and West African Dwarf goat (Getty, 1975; Dyce et al.; Onar et al., 2001; Olopade \& Onwuka, 2005, 2007). However, apart forms a preliminary report on the brain morphometry (Onwuka et al., 2003), dental eruption and oral pathologies (Otesile \& Obasaju, 1982; Kene \& Agbo, 1998), clinical applications of the mandibular and maxillofacial osteometry of the West African Dwarf goat (Olopade \& Onwuka, 2007, 2005) there is very little information on the regional clinical anatomy of the head of Black Bengal goats in available literatures. Therefore this study was designed to provide information on clinically important parameters and landmarks of head, those can may aid regional anesthesia be conducted in upper (maxilla) and the lower (mandible) jawbones of the Black Bengal goat.

\section{MATERIAL AND METHOD}

A total of 50 Back Bengal goats were used for this study. The live animals were first selected during antemortem examination at an abattoir based on parameters of apparent good health and no skeletal deformation. After slaughter, the heads were severed at the occipitoatlantal joint, purchased and processed in the anatomy laboratory of Chittagong Veterinary and Animal Sciences University using the hot water maceration techniques as described by Simoens et al., (1994) which briefly were:

1. On the working day, frozen goat head were allowed to thaw.

2. Skin and most of the muscles were separated and eyes were enucleated.

3. Heads were heated to over $80^{\circ} \mathrm{C}$ for at least 1 hour in solution of polycaboxylate and anionic surfactant (detergent) and soap chips.

4. Muscle of boiled heads were separated with the aid of forceps and scalpel in running water.

5. Further separation of muscles and ligaments from the skulls was done after left in detergent water at least 20-30 minutes.

6. Separation of remaining muscles and ligaments from the skull was done after left I n $1 \%$ sodium hypochlorite solution for at least 24 hours.

8. After that, the skulls were left in the above solution, for 48-72 hours with solution, being changed at least twice and clean in running tap water.

9. The skulls were then left to dry.

A total of 12 measurements were done in the upper jaw and mandibles using metric rules and the results were presented and as means \pm sd in Table I. The parameters measured of the upper and lower jawbones of the Black Bengal skulls are described below and shown in Figs.1- 4.
A. Facial tuberosity to infra-orbital canal: From the level of the most lateral bulging of the facial tuberosity to the mid level of the infra-orbital canal.

B. Infra-orbital canal to root of alveolar tooth: Measurement is taken vertically from the mid-level of the in infra-orbital canal to the root of the alveolar tooth.

C. Mandibular length: From the level of the cranial extremity of the alveolar root of the incisor to the level of the caudal border of the mandible.

D. Lateral alveolar root to mental foramen: Shortest distance from the mental foramen to the lateral extent of the alveolar root of lower incisor.

E. Mental foramen to the caudal mandibular border: From the level of the mental foramen to the extreme caudal border of the mandible.

F. Mandibular foramen to base of mandible: Vertical line from the ventral limit of the mandibular foramen to the base of the mandible.

G. Caudal border of mandible to below mandibular foramen: Length from the caudal most border of the mandible to the vertical line produced by description of measurement of mandibular foramen to base of the mandible.

H. Condyloid fossa to height of mandible: From the maximum height of mandible to the condyloid fossa.

I. Condyloid fossa to the base of the mandible.

J. Maximum mandibular height: From the basal level of the mandible to the highest level of the coronoid process.

K. Caudal border of mandibular to the level of mandibular foramen.

L. Mandibular foramen to mandibular angle: Shortest distance from the mandibular foramen to the extreme caudal border of the angle of the mandible.

\section{RESULTS AND DISCUSSION}

The distance from the facial tuberosity to the infraorbital canal and from the latter to the root of the alveolar tooth directly ventral to it were $1.85 \pm 0.14 \mathrm{~cm}$ and $1.75 \pm$ $0.19 \mathrm{~cm}$ respectively in Black Bengal goat (Fig. 1, Table I) while in West African Dwarfs goats were $1.6-1.8 \mathrm{~cm}$ and 
Table I. The measurements of the upper jaw and mandible of Black Bengal goats (cm).

\begin{tabular}{lcc}
\hline Item & Mean value & SD \\
\hline A & 1.85 & 0.14 \\
B & 1.75 & 0.19 \\
C & 14.21 & 0.98 \\
D & 2.11 & 0.17 \\
E & 11.69 & 0.40 \\
F & 3.64 & 0.23 \\
G & 1.47 & 0.25 \\
H & 2.36 & 0.23 \\
I & 6.38 & 0.51 \\
J & 8.83 & 0.57 \\
K & 0.90 & 0.15 \\
L & 2.65 & 0.31 \\
\hline
\end{tabular}

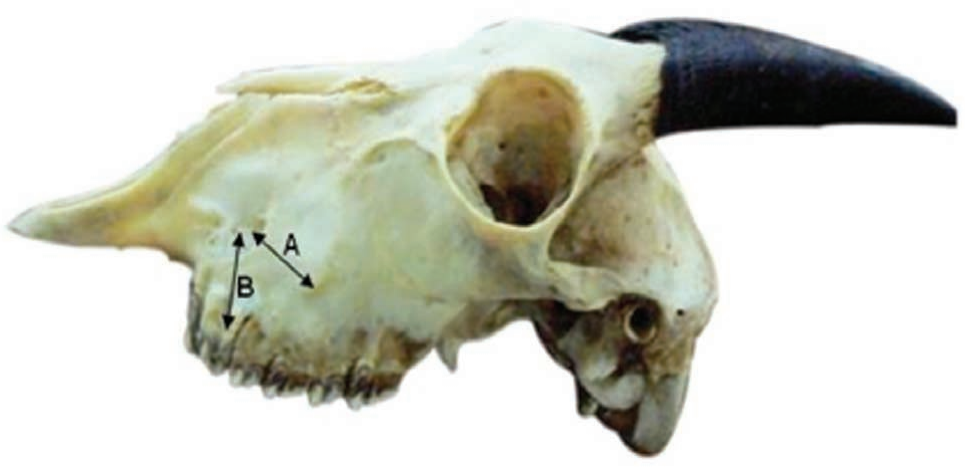

Fig. 1. Skull of Black Bengal goat; lateral view. A: Facial tuberousity to infraorbital canal. B: Infraorbital canal to root of alveolar tooth.

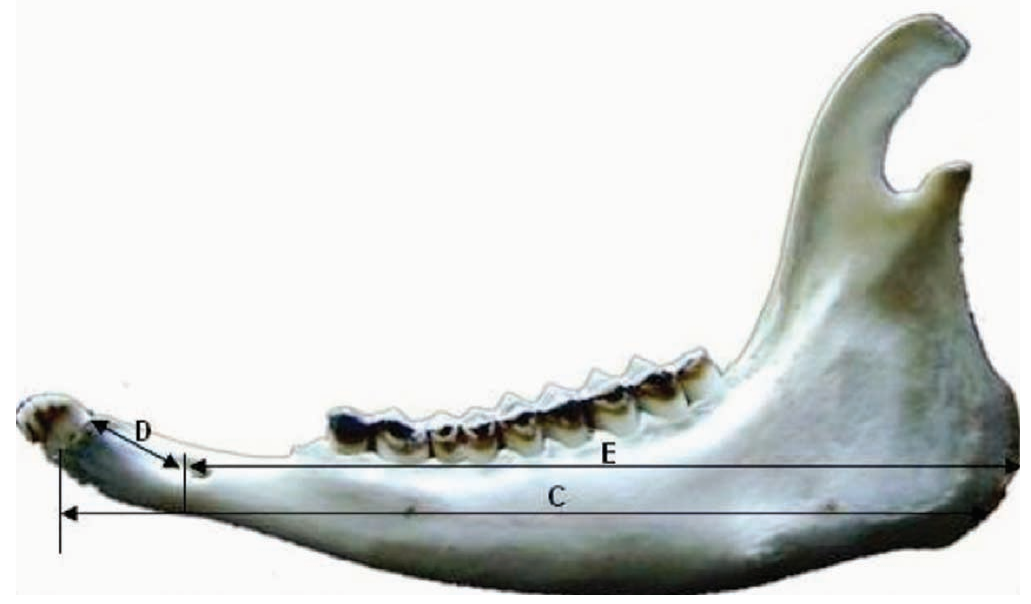

Fig. 2. Mandible of Black Bengal goat; lateral view. C: Mandibular length, D: Lateral alveolar root to mental foramen. E: Mental foramen to mandibular border.
$1.3-1.6 \mathrm{~cm}$. The data are of clinical importance because the facial tuberosity is very prominent even in live animals as a guide for tracking the infra-orbital nerve, and necessary for the desensitization of which affects the skin of the upper lip, nostril and face on that side of the level of the foramen. The injection of local anesthetic agents within the canal via the infra-orbital foramen will also lead to analgesia of the incisor, canine and first two premolars. Moreover, the infra-orbital foramen was located directly dorsal to the second or junction of the first and second upper premolar in Black Bengal goat where as in premolar two in Red Sokoto goats (Olopade \& Onwuka, 2007). This information coupled with the observed distance of $1.75 \mathrm{~cm}$ between the root of the teeth and the foramen would prove a vital guide to regional anesthesia involving the infra-orbital nerve in the Black Bengal goat.

The distance between the lateral end of the alveolus of the incisor tooth to the mental foramen was $2.11 \pm 0.17 \mathrm{~cm}$ (Fig. 2, Table 1) is an important landmark for the achieving the location of the mental nerve for this regional nerve block in Black Bengal goat while that was $1.6 \pm 0.22 \mathrm{~cm}$ and $2.0 \pm 0.3 \mathrm{~cm}$ in West African Dwarf goat and Red Sokoto (Maradi) goat of Nigeria respectively (Olopade \& Onwuka, 2005, 2007). In the anterior aspect of the mandibular canal, injection can be made through the mental foramen to desensitize mental aspect of the mandibular nerve. This will ensure the loss of sensation of the lower incisors, premolar and lower lip on that side (Hall et al.)

The mandiblular length of $14.21 \pm 0.98$ $\mathrm{cm}$ maximum mandibular height of $8.83 \pm 0.57$ $\mathrm{cm}$ in Black Bengal goat were higher than the value obtained for West African Dwarfs goats of Nigeria which were $12.00 \pm 1.89 \mathrm{~cm}$ and $6.90 \pm 1.09 \mathrm{~cm}$ respectively (Olopade \& Onwuka, 2005), similar observations were seen in the values of the distances between the condyloid fossa to height of mandible, Condyloid fossa to the base of the mandible, Mandibular formen to base of mandible (Figs 2, 3) (Olopade \& Onwuka, 2005, 2007).The caudal border of the mandible to the vertical line downwards form the middle of the mandibular foramen (Fig. 3) was $1.47 \pm 0.25$ $\mathrm{cm}$, while the distance from the mandibular foramen to the base of the mandible, Caudal border of mandibular to the level of mandibular foramen and mandibular foramen to border of 


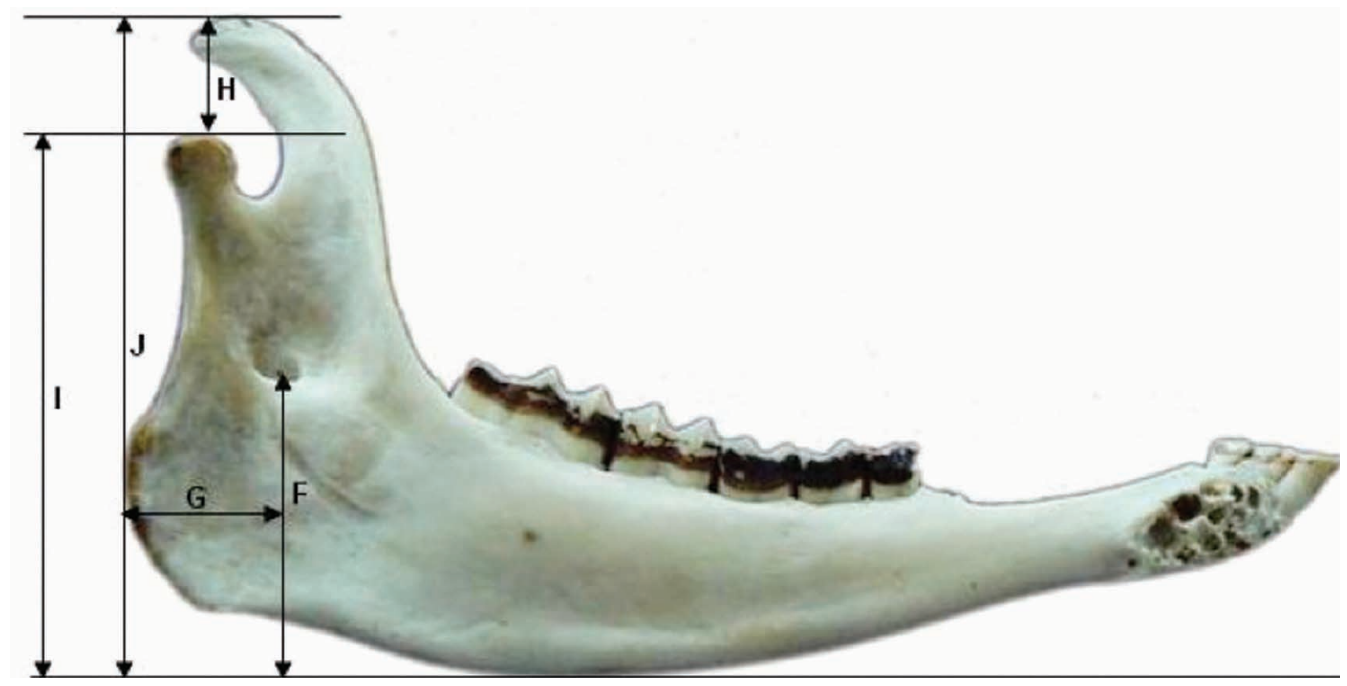

Fig. 3. Mandible of Black Bengal goat; Medial view. F: Mandibular formen to base of mandible, G: Caudal border of mandible to below mandibular foramen, H: Condyloid fossa to height of mandible, I: Condyloid fossa to the base of the mandible, J: Maximum mandibular height.

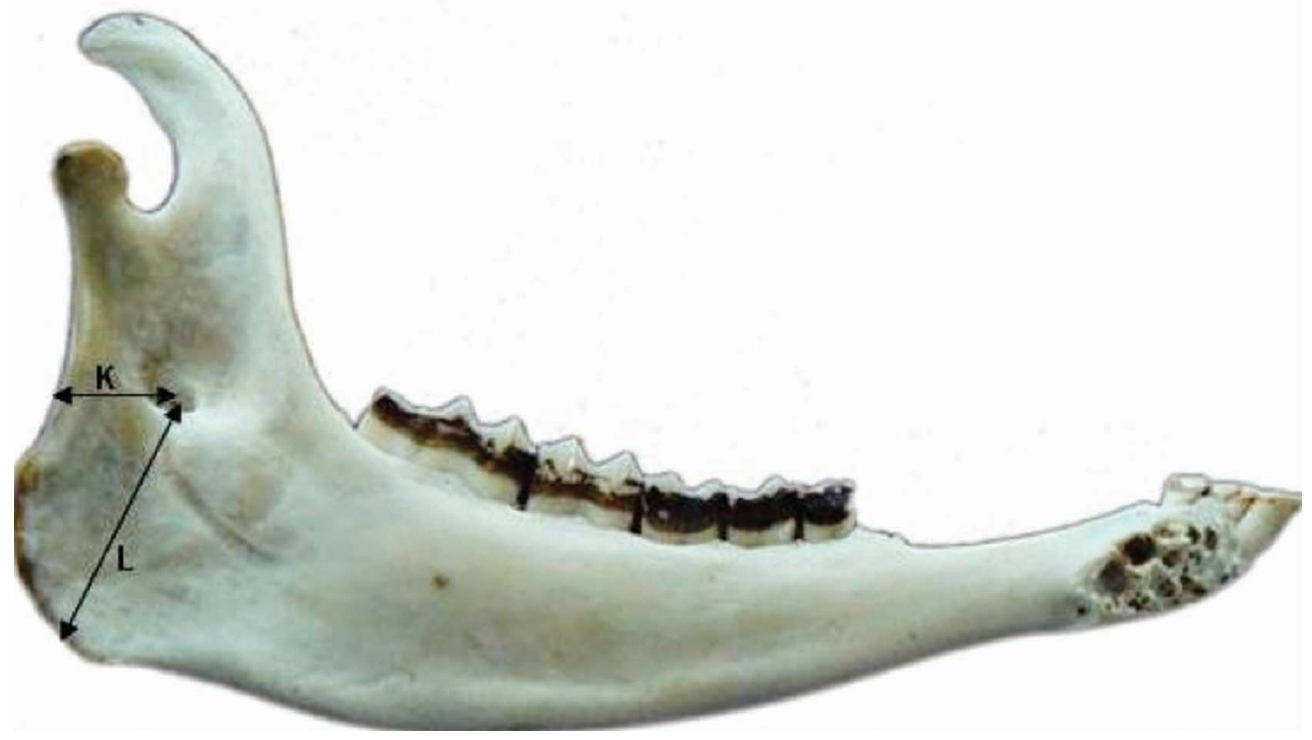

Fig. 4. Mandible of Black Bengal goat; medial view. K: Caudal border of mandibular to the level of mandibular foramen. L: Mandibular foramen to border of mandibular angle.

mandibular angle were $3.64 \pm 0.23 \mathrm{~cm}, 0.90 \pm 0.15 \mathrm{~cm}$ and $2.65 \pm 0.31 \mathrm{~cm}$ respectively (Fig $3 \& 4$, Table 1). These parameters are of clinical important landmarks that will aid the regional anesthesia of mandibular nerve block, necessary for desensitization of all the teeth in lower jaw of the side of the block (Hall et al., 2000). Equivalent figures for West African Dwarfs goats of Nigeria were $1.57 \pm 0.44 \mathrm{~cm}, 2.58$ $\pm 0.34 \mathrm{~cm}$ respectively for Caudal border of mandible to below mandibular foramen and mandibular foramen to the base of the mandible (Olopade \& Onwuka, 2005) though in the horse and dogs were $3 \mathrm{~cm}$ and 1.5 to $2 \mathrm{~cm}$ respectively for the distance between the mandible foramen and base of the mandible (Hall et al.).

As earlier stated, there is no previous information on these parameters in Black Bengal Goat, nor in any other goat breeds and domestic animals in Bangladesh with which comparisons could be made. We therefore believe that the data presented above will form a vital baseline for further work especially comparability and compatibility are now desirable traits as efforts are geared up towards massive improvement in the livestock sector of the international economy. 
UDDIN, M. M.; AHMED, S. S. U.; ISLAM, K. N. \& ISLAM, M. M. Anatomía clínica de la región de cabeza de la cabra Negra Bengal en Bangladesh. Int. J. Morphol., 27(4):1269-1273, 2009.

RESUMEN: El estudio incluyó la medición de algunos puntos anatómicos de importancia clínica para la anestesia regional en las regiones superior e inferior de la cabeza de cincuenta cabras Negras de Bengal (BB). La distancia desde la tuberosidad facial hasta el canal infraorbitario y de éste a la raíz del diente alveolar directamente ventral a él fueron $1,85 \mathrm{~cm}$ y $1,75 \mathrm{~cm}$, respectivamente. Tanto las distancias desde la tuberosidad facial hasta el canal infraorbitario y desde el canal infraorbitario a la raíz del diente alveolar fueron importancia clínica en animales vivos como una guía para el seguimiento del nervio infraorbitario a través de la tuberosidad facial. La distancia entre el extremo lateral de los alvéolos de los dientes incisivos al foramen mental fue de 2,11 cm y desde el foramen mental al borde mandibular caudal fue $11,69 \mathrm{~cm}$ y es importante para la anestesia regional del nervio mentoniano. La longitud y la altura máxima de las mandíbulas fueron $14,21 \mathrm{~cm}$ y $8,83 \mathrm{~cm}$ respectivamente. La distancia desde el borde caudal de la mandíbula por debajo del foramen mandibular fue de $1,47 \mathrm{~cm}$, mientras que la distancia desde el foramen mental hasta la base de la mandíbula, desde el borde caudal de la mandíbula a nivel del foramen mandibular y del foramen mandibular hasta el borde del ángulo mandibular fueron $3,64 \mathrm{~cm}, 0,90 \mathrm{~cm}$ y 2,65 cm, respectivamente. Los parámetros en relación con la mandíbula son puntos anatómicos de importancia clínica y sirven de guía para la anestesia regional del bloqueo del nervio mandibular. No obstante, estos datos fueron discutidos en relación a su aplicación en el seguimiento adecuado de las infraestructuras de los nervios infraorbitario, mental y mandibular en ayuda a procedimientos anestésicos regionales para el uso clínico alrededor de la cabeza de cabra de Bengal Negra.

PALABRAS CLAVE: Mandíbula; Maxilar; Anestesia regional; Cabra.

\section{REFERENCES}

Dyce, K. M.; Sack, W. O. \& Wensing, C. J. G. Textbook of Veterinary Anatomy. 2. ed. Philadelphia, Saunders, 1996.

Getty, R. Sisson and Grossman's The Anatomy of the Domestic Animals. $5^{\text {th }}$ Ed. Philadelphia, Saunders, 1975.

Hall, L. W; Clarke, K. W \& Trim, C. M. Wright's Veterinary Anaesthesia and Analgesia. 10 Ed. London, ELBS and Baillierre Tindall, 2000.

Islam, M.; Nahar, T. N. \& Hoq, S. Prospect of goat production in Bangladesh. Asian Livestock XVI: 85-95, 1991.

Kene, R. O. C. \& Agbo, C. N. Dental abnormalities of three breeds of Nigerian goat. Tropical Veterinarian, 16:15-22, 1998.

Olopade, J. O. The Morphometry of the craniofacial and maxillofacial regions of the West African Dwarf Goats (Capra hircus). M. Sc. thesis, Department of Veterinary Anatomy, University of Ibadan, Ibadan, Nigeria, 2003.

Olopade, J. O. \& Onwuka, S. K. Some Aspects of the Clinical Anatomy of the Mandibular and Maxillofacial Regions of the West African Dwarf Goat in Nigeria. Int. J. Morphol., 23(1):33-6, 2005.

Olopade, J. O. \& Onwuka, S. K. Osteometric Studies of the Red Sokoto (Maradi) Goats (Capra hircus): Implication for Resional Anaesthesia of the Head. Int. J. Morphol., 25(2):407-10, 2007.

Onar, V.; Ozcan, S. \& Pazvant, G. Skull Typology of Adult male kangal dog. Anat. Histol. Embryol., 30:41-8, 2001.
Onwuka, S. K; Olopade, J. O.; Babajide, B. F. \& Ehimiyien I. O. Preliminary morphometric investigation of the brain of West African Dwarf Goat. Procceedings of the 39th Annual Conference of the Nigerian Veterinary Medical Association held in Sokoto, Nigeria, 2003. pp.57-9,

Otesile, E. B. \& Obasaju, M. F. Relationship between age rostral teeth development in Nigerian goats. In proceedings of the 3rd international conference on Goat Production and Disease University of Arizona. Tucson, U.S.A, 1982.

Simoens, R.; Poles, R. \& Lauwers, H. Morphometric analysis of foramen magnum in pekingese dogs. Am. J. Vet. Res., 55:33-9, 1994.

Singh, D. K.; Misra H. R. \& Singh, C. S. P. Genetic and nongenetic factors affecting post-weaning survivability in kids. Anim. Prod, 51:559-64, 1990.

Singh, D. K.; Singh, C. S. P. \& Misra, H. R. Factors affecting growth of Black Bengal and its crossbreds with Jamnapari and Beetal goats. Indian J. Anim. Sci., 61:1101-5, 1991.

Correspondence to:

Mohammad Mejbah Uddin

Assistant Professor, Department of Anatomy and Histology,

Faculty of Veterinary Medicine

Chittagong Veterinary and Animal Sciences University

Khulshi, Chittagong-4202.

Bangladesh.

Phone: +88-0172-1020665, Fax- +88-031-659020

Email: mmu_cvasu@yahoo.com

Received: 13-05-2009

Accepted: 25-08-2009 
